\title{
EFFECT OF POURING TEMPERATURE AND DEGASSING ON THE CASTING QUALITY OF Al 6061: EXPERIMENTAL AND NUMERICAL STUDY
}

\author{
RENDI* \\ Department of Materials and Metallurgical Engineering, \\ Institut Teknologi Sepuluh Nopember, \\ Kampus ITS Keputih Sukolilo, 60111, Surabaya, East Java, Indonesia \\ rendi_251@yahoo.co.id \\ ALVIAN T. WIBOWO \\ Department of Materials and Metallurgical Engineering, \\ Institut Teknologi Sepuluh Nopember, \\ Kampus ITS Keputih Sukolilo, 60111, Surabaya, East Java, Indonesia \\ alviantotow@gmail.com \\ MAS IRFAN P. HIDAYAT \\ Department of Materials and Metallurgical Engineering, \\ Institut Teknologi Sepuluh Nopember, \\ Kampus ITS Keputih Sukolilo, 60111, Surabaya, East Java, Indonesia \\ irfan@mat-eng.its.ac.id \\ * Corresponding author
}

Received 1 December 2021; Published 31 December 2021

\begin{abstract}
As one of important components of an airplane, body of airplane is required to have high value of strength to weight ratio. In this study, transient heat transfer of $\mathrm{Al} 6061$ in a sand casting process was investigated both experimentally and numerically. The effects of different pouring temperatures $\left(700,720\right.$ and $740{ }^{\circ} \mathrm{C}$ ) and presence of thin film and $\mathrm{H} 2$ inclusions are considered in the present study. Composition, XRD, metallography and tensile strength tests have been carried out to examine the casting product quality, before and after degassing, a process to remove the inclusions from the cast. Correspondingly, heat transfer simulations were carried out by taking into account the variation of pouring temperatures and the presence of inclusions. From the present experimental and numerical study, it was found that: (i) Degassing enhanced significantly the strength of $\mathrm{Al} 6061$ product. The highest tensile strength value has been found to be $64.30 \mathrm{MPa}$, related to the pouring temperature of $700{ }^{\circ} \mathrm{C}$ with degassing, while the lowest one is $35.85 \mathrm{MPa}$ associated with the pouring temperature of $700{ }^{\circ} \mathrm{C}$ without degassing. (ii) Pouring temperature did not affect significantly to the strength of Al 6061 product, especially when degassing process was carried out, and (iii) The presence of thin film and hydrogen gas inclusions affected the cooling rate of the metal slab. Overall, the cooling of the metal slab with thin film inclusion became slower, while the cooling of the metal slab with hydrogen gas inclusions became faster.
\end{abstract}

Keywords: Sand casting; Al 6061; pouring temperature; degassing; heat transfer; mechanical strength.

\section{Introduction}

Aluminum 6061 is a main component for an airplane body. The material has a strength of $128 \mathrm{MPa}$ for as-cast and up to $310 \mathrm{MPa}$ for T-6 type (American Society for Testing and Materials, 2002; Totten and MacKenzie, 2003). In this study, both experimental and numerical study on sand casting process of $\mathrm{Al} 6061$ was carried out. In particular, transient heat transfer of Al 6061 the process is investigated. The effects of different pouring temperatures (700, 720 and $740{ }^{\circ} \mathrm{C}$ ) and presence of thin film and $\mathrm{H} 2$ inclusions are considered in the present study. Composition, XRD, metallography and tensile strength tests have been carried out to examine the casting product quality, before and after degassing, a process to remove the inclusions from the cast. Correspondingly, heat transfer simulations were carried out by taking into account the variation of pouring temperatures and the presence of inclusions. 
Rendi et al.

\section{METHODS}

\subsection{Material}

Raw materials Al ingot of 99.9\% from PT Inalum, Mg ingot of 90\% from PT Pinjaya Logam and Al-7.92\%Si from PT Pinjaya Logam were used in this research study. The compositions are:

Table 1. Design for composition of Al 6061 (\%wt)

\begin{tabular}{cccc}
\hline \hline Alloy & Al (\%) & Si (\%) & Mg (\%) \\
\hline Al 6061 ND & 98 & 0.618 & 1.49 \\
\hline Al 6061 D & 98 & 0.618 & 1.49 \\
\hline
\end{tabular}

\subsection{Casting Process and Testing}

Electric furnace was used for the casting process. Pouring temperatures were varied as: $700^{\circ} \mathrm{C}, 720^{\circ} \mathrm{C}$ and $740^{\circ} \mathrm{C}$ for both degassing (D) and non-degassing (ND). Based upon the design for composition as shown in Table 1, the materials were melted and poured into a sand casting mold to cast testing specimens. The mold was green sand.

Optical Emission Spectroscopy (OES) in the Laboratory of Surabaya Shipbuilding State Polytechnic (PPNS) was used for the identification of chemical composition. Tensile testing was carried out in the Department of Naval Architecture, ITS Surabaya based on the ASTM B 557M standard (American Society for Testing and Materials, 2002). In addition, to identify phase transformation in the alloy after the process, XRD testing was carried out in the Division of Materials Characterization, ITS Surabaya by using PAN Analytical XRD machine. Filament of $\mathrm{Cu}$ is used with the current $\mathrm{I}=30 \mathrm{~mA}$ and voltage $\mathrm{V}=40 \mathrm{kV}$. Further, metallography was carried for microstructure observation by using an optical microscope type OLYMPUS BX51M-RF in the Laboratory of Metallurgy, Department of Materials and Metallurgical Engineering, ITS Surabaya.

\subsection{Heat Transfer Simulation}

For the heat transfer simulation, geometry and meshing of the casting mold, including the shapes of thin film and hydrogen inclusion, were prepared by using ANSYS Mechanical APDL 18.1. Open molding was chosen in this study. SOLID278 element (brick8node278) was chosen for the thermal simulation in order to obtain transient temperature history and distribution during the casting process (Firdaus et al., 2016; Anwar et al., 2020).
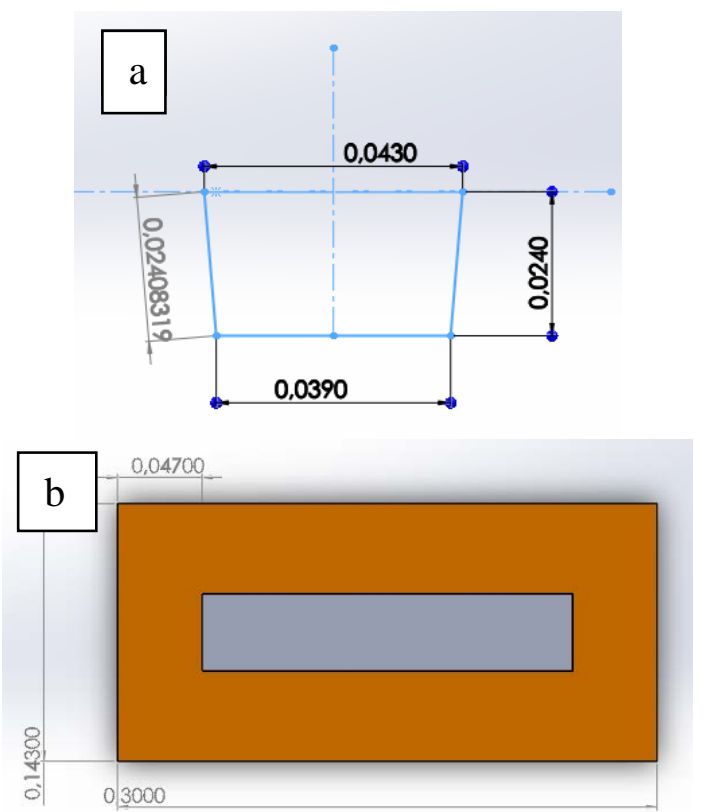

Fig. 1. Casting mold: (a) Front, and (b) Top views. 
Rendi et al.

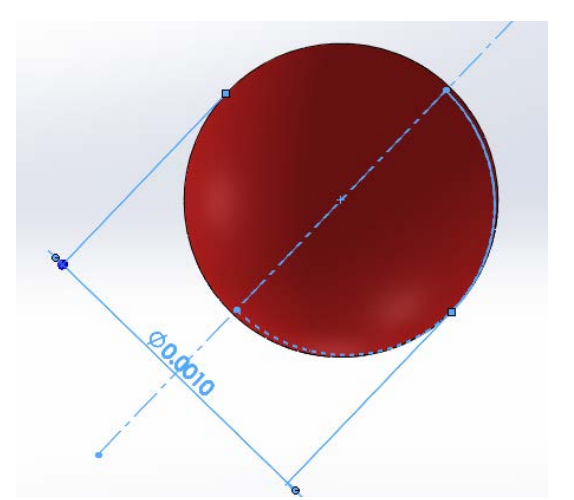

Fig. 2. Hydrogen inclusion.

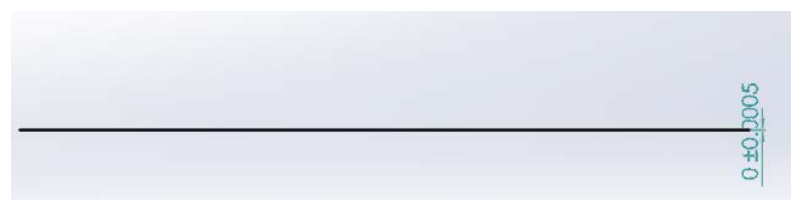

Fig. 3. Thin film geometry.

Fig. 1 shows the casting geometry, while hydrogen inclusion with diameter of $1 \mathrm{~mm}$ and thin film of $50 \mu \mathrm{m}$ thickness are shown in Figs. 2 and 3, respectively.

\section{Results and Discussion}

\subsection{Al 6061 Composition}

As mentioned previously, casting process in this study used raw materials Al ingot of 99.9\%, Mg ingot of $90 \%$ and Al-7.92\%Si. The actual chemical composition of Al 6061 obtained from the casting is shown in Table 2. It is observed that there is a discrepancy between the design and actual chemical composition. It is due to oxidation process where $\mathrm{Mg}$ and $\mathrm{Al}$ react into $\mathrm{MgO}$ and $\mathrm{Al}_{2} \mathrm{O}_{3}$. Based upon Ellingham diagram, the oxidation products will form slag (Shamsuddin, 2016). The slag can be removed through degassing and skimming processes (Gerrard, 2014).

Table 2. Chemical composition of Al 6061 (\%wt)

\begin{tabular}{cccc}
\hline \hline Alloy & Al (\%wt) & Si (\%wt) & Mg (\%wt) \\
\hline Al 6061 ND & 97.7 & 0.714 & 1.45 \\
\hline Al 6061 D & 97.7 & 0.714 & 1.52 \\
\hline
\end{tabular}

\subsection{XRD Result}

Phase transformation in Al 6061 was observed through X-ray diffraction. The XRD results can be seen in Fig. 4. Peaks corresponding to alpha $\mathrm{Al}(\alpha)$ can be observed for both $\mathrm{Al} 6061 \mathrm{ND}$ and $\mathrm{Al} 6061 \mathrm{D}$, in which $\mathrm{Mg}_{2} \mathrm{Si}$ is still dissolved in the $\mathrm{Al}$ crystal lattice structure. The $\mathrm{Mg}_{2} \mathrm{Si}$ precipitate will be commonly formed when $\mathrm{Al} 6061$ undergoes age hardening (Avner, 1974). The phase formed is Al with FCC crystal structure. 
Rendi et al.

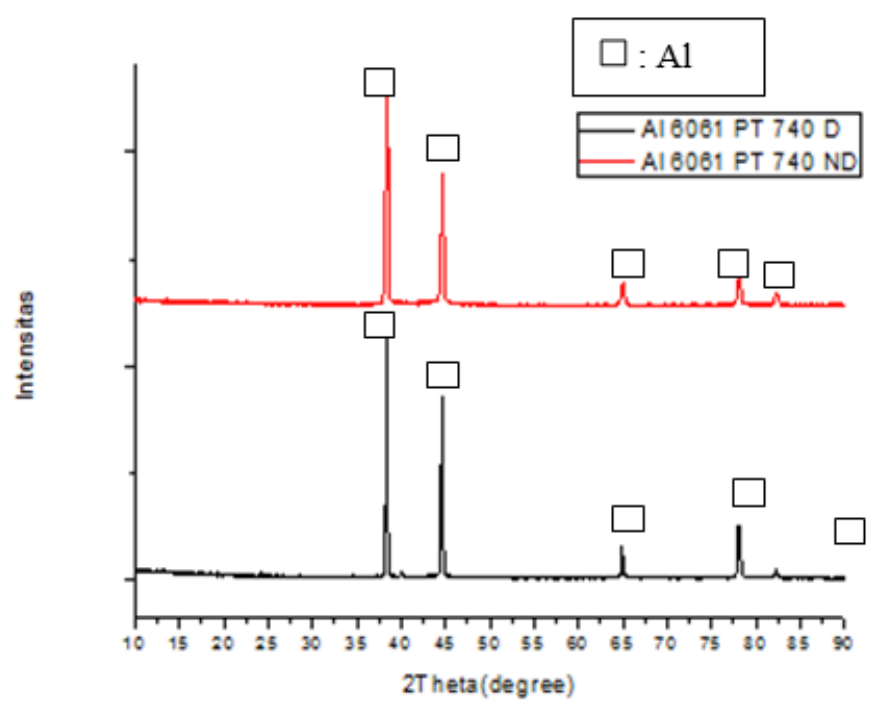

Fig. 4. XRD results for Al 6061 after casting.

\subsection{Al 6061 Microstructure}

Microstructure of $\mathrm{Al} 6061$ was observed by using metallography technique following ASM Vol 9 (ASM International, 2004). The etching solution has a composition of $190 \mathrm{ml}$ aquades, $3 \mathrm{ml} \mathrm{HCl,} 5 \mathrm{ml} \mathrm{HNO}$ and $2 \mathrm{ml}$ HF and given to the specimen by using immerse method for 10-20 seconds. The microstructures of Al 6061 are shown in Fig. 5.

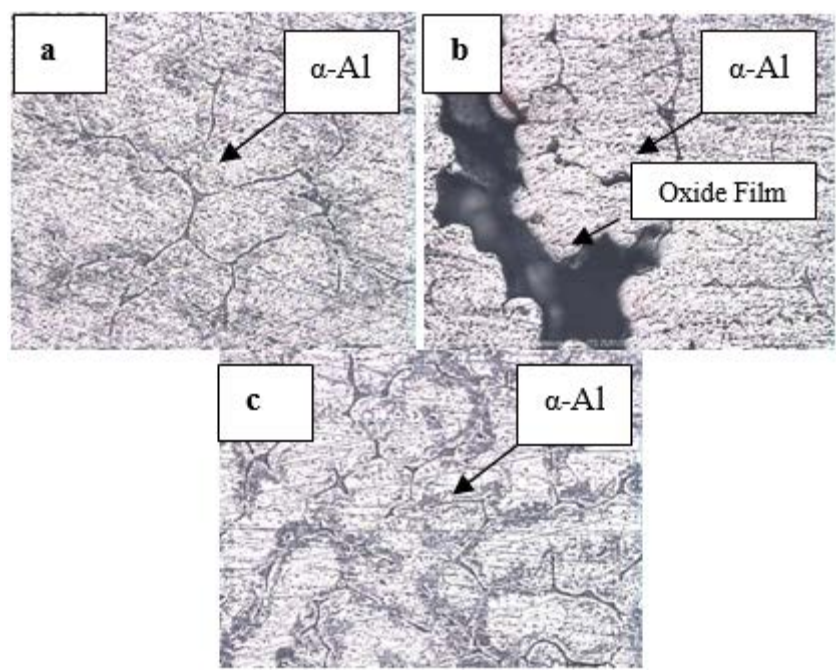

Fig. 5. Microstructures: (a) Al 6061 PT $740^{\circ} \mathrm{C}$ ND, (b) Al 6061 PT $740^{\circ} \mathrm{C}$ ND with defect, and (c) Al 6061 PT $740^{\circ} \mathrm{C}$ D.

Fig. 5 depicts microstructures of $\mathrm{Al} 6061$ obtained from pouring temperature of $740^{\circ} \mathrm{C}$ without degassing (a and b) and with degassing (c), at magnification of 100x. It is observed that the product of Al 6061 without degassing has defect in the form of oxide film. This is due to a reaction between aluminium and oxygen during the casting process (Eisaabadi B. et al., 2012). On the other hand, the product of Al 6061 followed by degassing did not show any defect in the microstructure as slag can be removed through the process. It is also noted that both $\mathrm{Al} 6061 \mathrm{ND}$ and $\mathrm{Al} 6061 \mathrm{D}$ possesses the same phase i.e. $\alpha$-Al confirmed from the XRD results. 
Rendi et al.

\subsection{Tensile Test of Al 6061}

Effects of pouring temperature and degassing to the value of ultimate tensile strength (UTS) of the products were also examined in this study. Metal cylinder specimens following ASTM B 557M were used (American Society for Testing and Materials, 2002). The tensile test results are shown in Tabel 3.

Table 3. UTS of Al 6061 specimens

\begin{tabular}{lll}
\hline \hline Pouring Temperature $\left({ }^{\circ} \mathrm{C}\right)$ & Alloy (Product ID) & UTS (MPa) \\
\hline 700 & Al 6061 700 ND & $35.85 \pm 5$ \\
\hline 720 & Al 6061 720 ND & $39.57 \pm 0,5$ \\
\hline 740 & Al 6061 740 ND & $47.68 \pm 18$ \\
\hline 700 & Al 6061 700 D & $64.30 \pm 4$ \\
\hline 720 & Al 6061 720 D & $56.99 \pm 4$ \\
\hline 740 & Al 6061 740 D & $61.34 \pm 13$ \\
\hline
\end{tabular}

From Table 3, it can be seen that the $\mathrm{Al} 6061$ product obtained by using pouring temperature of $700^{\circ} \mathrm{C}$ followed with degassing has the highest UTS value, while its counterpart has the lowest UTS value. The process of degassing has indeed increased the strength of material by removing inclusions/slags in the molten metal (Rao, 1999). On the other hand, while the UTS value is affected by the pouring temperature in the casting process without degassing, it is not the case in the casting process with degassing i.e. the increase of pouring temperature did not always yield better UTS values.

\subsection{Results of Heat Transfer Simulation}

Temperature history and distribution in the metal slab were obtained from the finite element (FE) simulation. In the heat transfer simulation, the final time was set to be 60 minutes $(3600 \mathrm{~s}$ ). The value of convection coefficient was taken as $11.45 \mathrm{~W} / \mathrm{m} . \mathrm{K}$ (Pariona and Mossi, 2005; Yogatama et al., 2020). The variation of pouring temperature was $700^{\circ} \mathrm{C}, 720^{\circ} \mathrm{C}$, and $740^{\circ} \mathrm{C}$, respectively, which was the same as in the experimental study. Bulk/surrounding/environment temperature was set to be $30^{\circ} \mathrm{C}$.

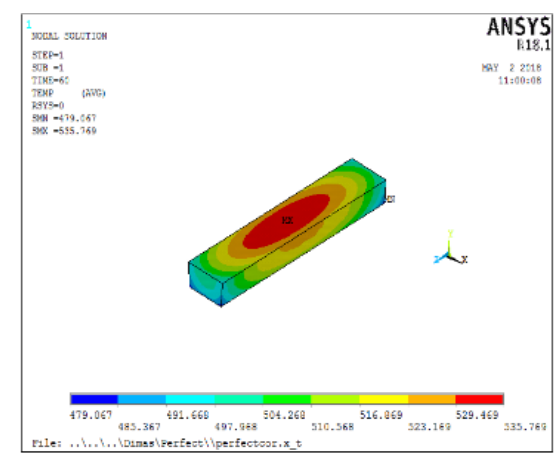

(a)

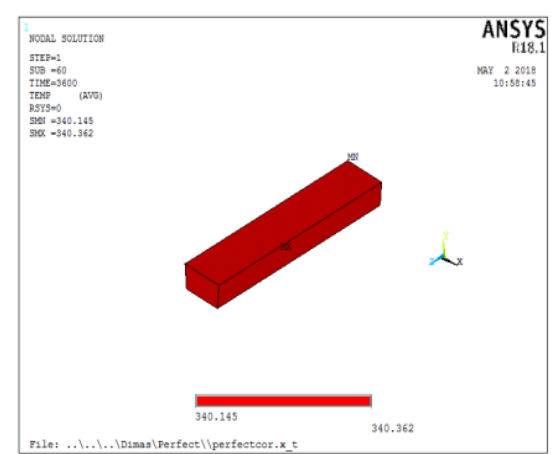

(b)

Fig. 6. Temperature distribution of $\mathrm{Al} 6061 \mathrm{D}$ (without inclusions) with pouring temperature of $700^{\circ} \mathrm{C}$ during cooling at: (a) $60 \mathrm{~s}$ and (b) $3600 \mathrm{~s}$. 
Rendi et al.

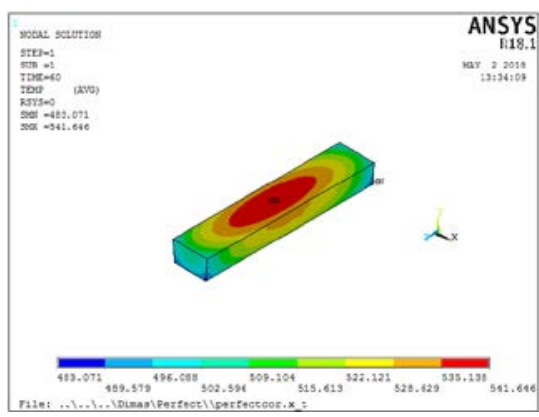

(a)

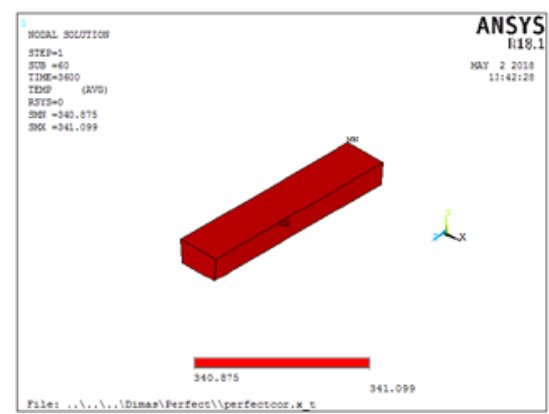

(b)

Fig. 7. Temperature distribution of $\mathrm{Al} 6061 \mathrm{D}$ (without inclusions) with pouring temperature of $720^{\circ} \mathrm{C}$ during cooling at: (a) $60 \mathrm{~s}$ and (b) $3600 \mathrm{~s}$.

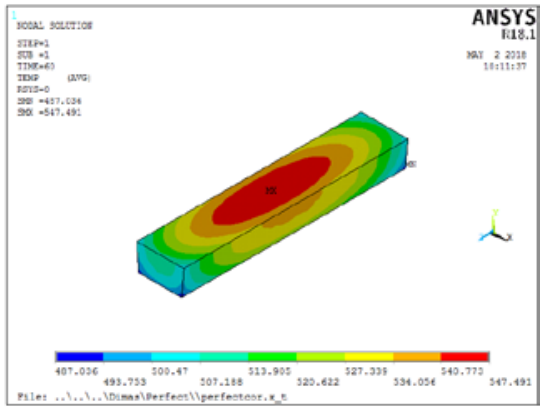

(a)

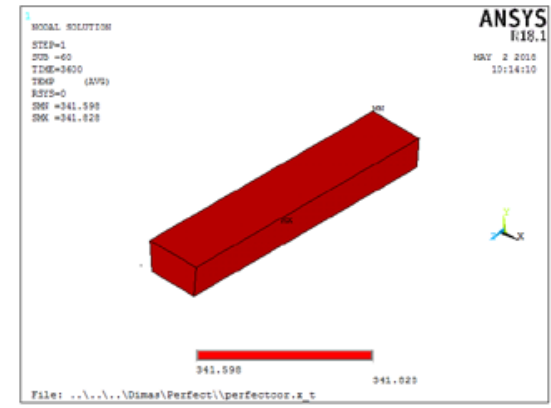

(b)

Fig. 8. Temperature distribution of $\mathrm{Al} 6061 \mathrm{D}$ (without inclusions) with pouring temperature of $740^{\circ} \mathrm{C}$ during cooling at: (a) $60 \mathrm{~s}$ and (b) $3600 \mathrm{~s}$.

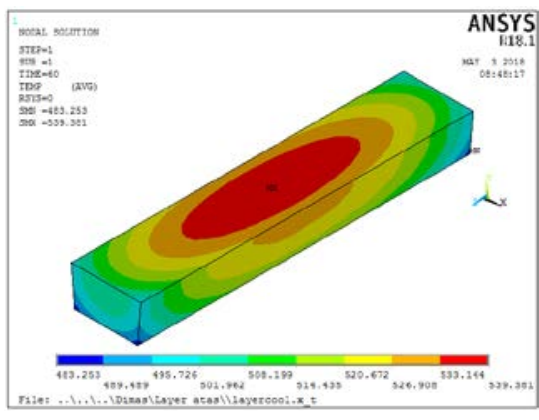

(a)

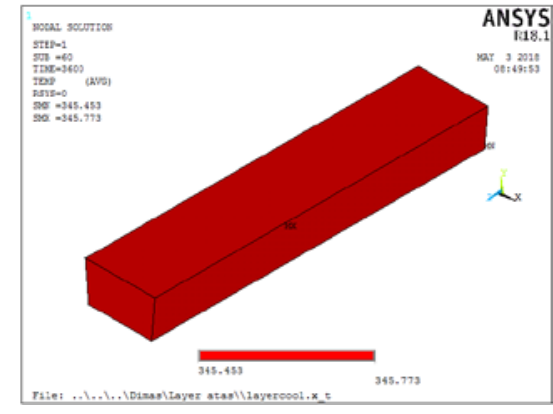

(b)

Fig. 9. Temperature distribution of $\mathrm{Al} 6061 \mathrm{ND}$ (thin film inclusion) with pouring temperature of $700^{\circ} \mathrm{C}$ during cooling at: (a) $60 \mathrm{~s}$ and (b) $3600 \mathrm{~s}$. 
Rendi et al.

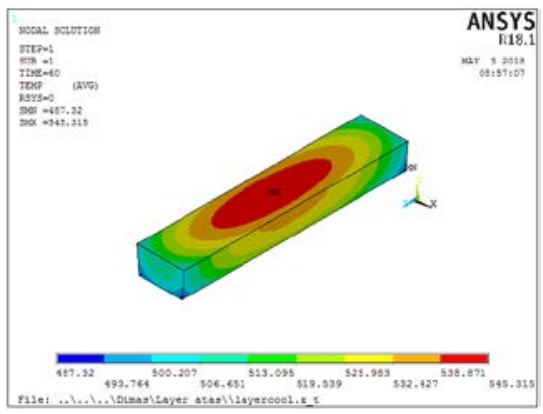

(a)

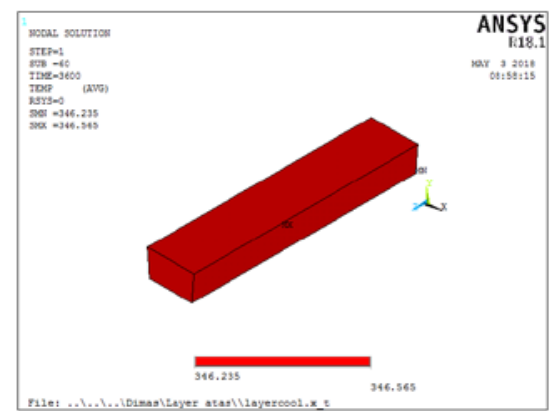

(b)

Fig. 10. Temperature distribution of Al $6061 \mathrm{ND}$ (thin film inclusion) with pouring temperature of $720^{\circ} \mathrm{C}$ during cooling at: (a) $60 \mathrm{~s}$ and (b) $3600 \mathrm{~s}$.

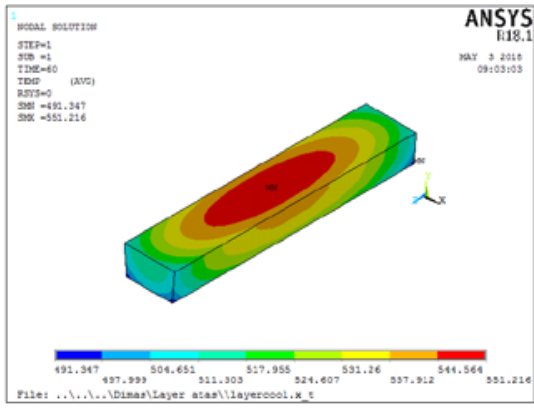

(a)

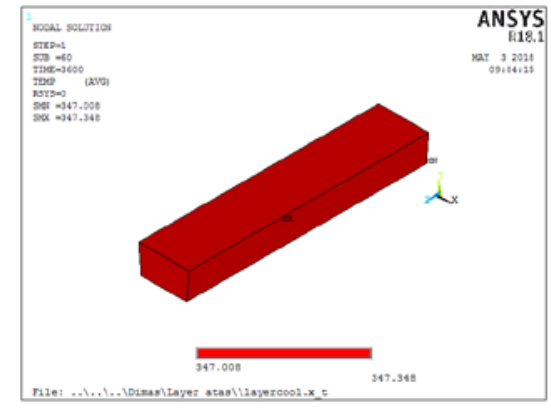

(b)

Fig. 11. Temperature distribution of Al $6061 \mathrm{ND}$ (thin film inclusion) with pouring temperature of $740^{\circ} \mathrm{C}$ during cooling at: (a) $60 \mathrm{~s}$ and (b) $3600 \mathrm{~s}$.

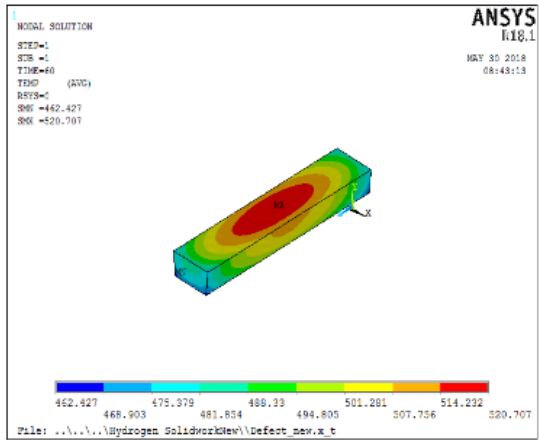

(a)

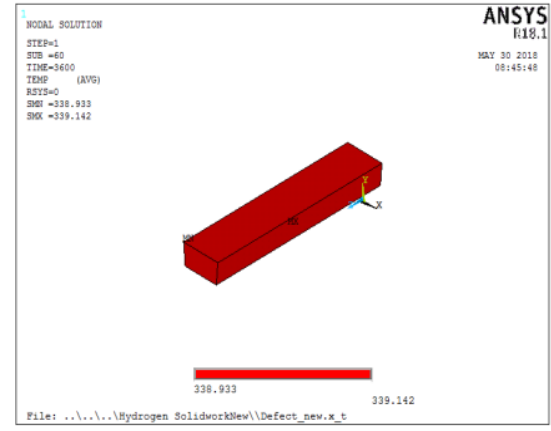

(b)

Fig. 12. Temperature distribution of Al 6061 ND (hydrogen inclusion) with pouring temperature of $700^{\circ} \mathrm{C}$ during cooling at: (a) $60 \mathrm{~s}$ and (b) $3600 \mathrm{~s}$. 
Rendi et al.

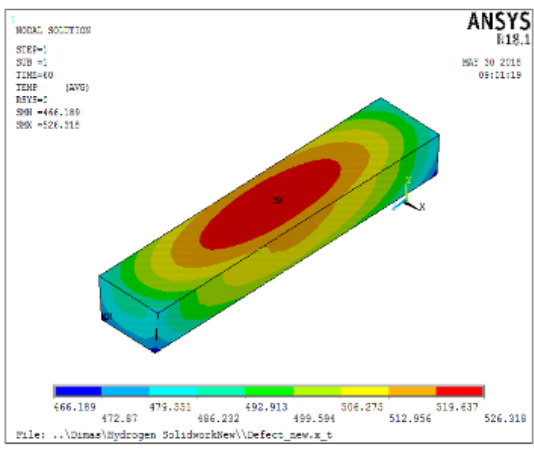

(a)

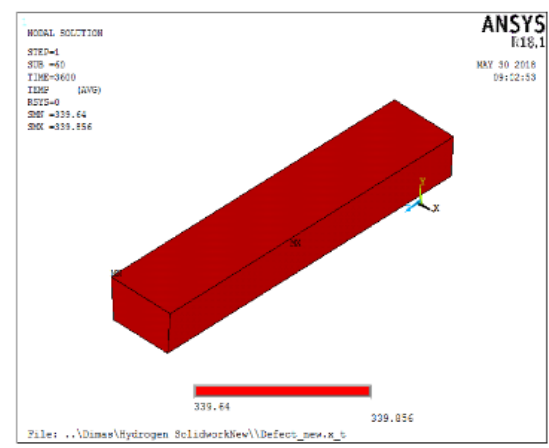

(b)

Fig. 13. Temperature distribution of $\mathrm{Al} 6061 \mathrm{ND}$ (hydrogen inclusion) with pouring temperature of $720^{\circ} \mathrm{C}$ during cooling at: (a) $60 s$ and (b) $3600 s$.

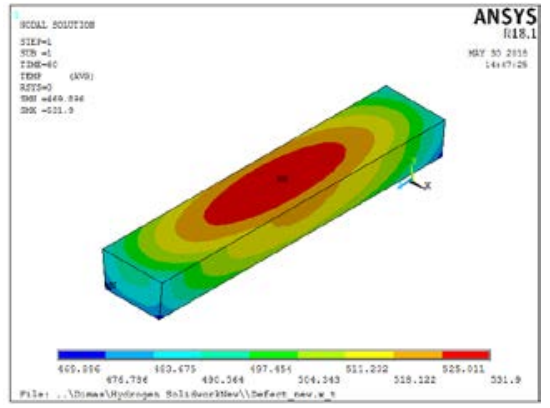

(a)

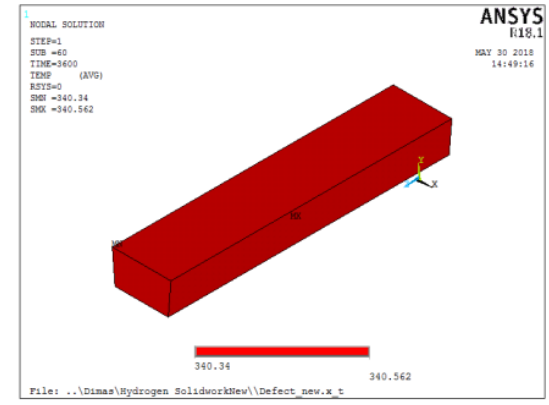

(b)

Fig.14. Temperature distribution of Al 6061 ND (hydrogen inclusion) with pouring temperature of $740^{\circ} \mathrm{C}$ during cooling at: (a) $60 \mathrm{~s}$ and (b) $3600 \mathrm{~s}$.

Figs. 6-14 show the metal slab during cooling. As can be observed, cooling firstly starts at molten metal parts which are in contact with the sand mold. Also, the metal slab with thin film inclusion experienced slower cooling process. On the other hand, the metal slab with hydrogen inclusion experienced faster cooling process. It is seen that cooling rate at the beginning of cooling process took place with higher rate than that of subsequent times. Afterward, the cooling rate became slower having the temperature differences in the slab became lower as well due to the decrease of temperature.

For clarity of presentation, temperature history and distribution inside the thin film inclusion only are shown in Figs. 15-17. It is observed that the thin film experienced fast cooling rate so as to its temperature has already reached room temperature after $900 \mathrm{~s}$. On the other hand, as can be seen in Figs. 18-20 the hydrogen inclusions had lower cooling rate compared with the thin film. At $900 \mathrm{~s}$, their temperature still have not reached the room temperature yet, although comparable with the slab temperature. It is important to note that in the present study the number of hydrogen inclusions have not been checked for their adequacy and distributions throughout the metal slab. It is interesting to note that overall the presence of thin film and hydrogen gas inclusions affected the cooling rate of the metal slab, as shown in Figs. 9-14. 
Rendi et al.

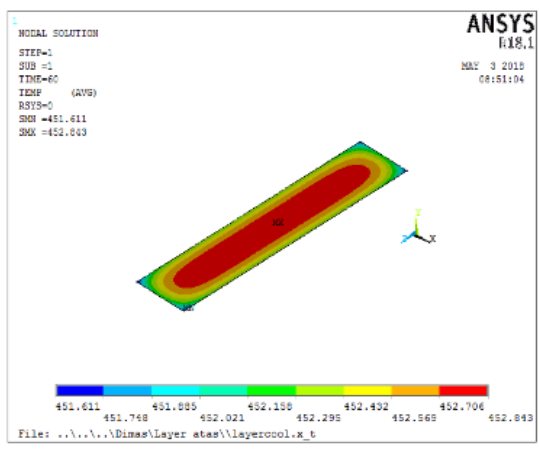

(a)

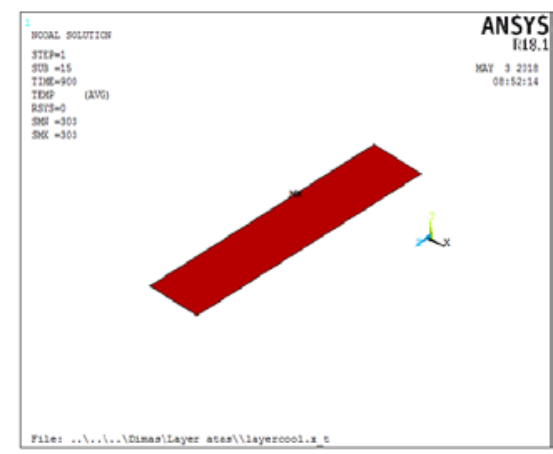

(b)

Fig. 15. Temperature distribution of thin film inclusion with pouring temperature of $700^{\circ} \mathrm{C}$ at: (a) $60 \mathrm{~s}$ and (b) $900 \mathrm{~s}$.

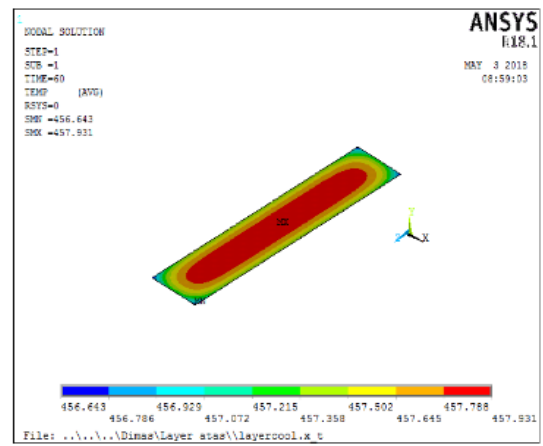

(a)

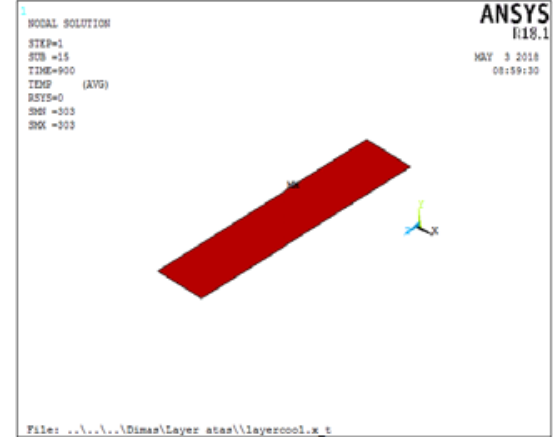

(b)

Fig. 16. Temperature distribution of thin film inclusion with pouring temperature of $720^{\circ} \mathrm{C}$ at: (a) $60 \mathrm{~s}$ and (b) $900 \mathrm{~s}$.

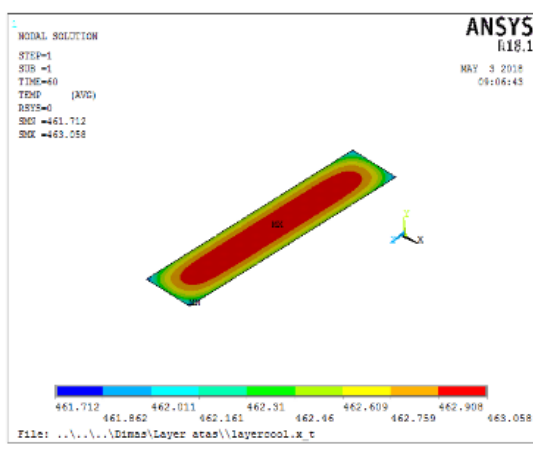

(a)

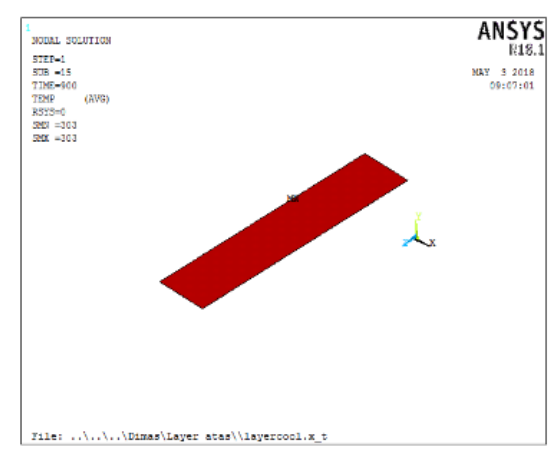

(b)

Fig. 17. Temperature distribution of thin film inclusion with pouring temperature of $740^{\circ} \mathrm{C}$ at: (a) $60 \mathrm{~s}$ and (b) $900 \mathrm{~s}$. 
Rendi et al.

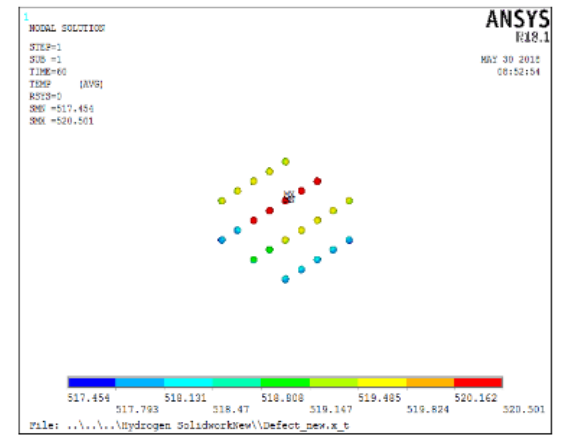

(a)

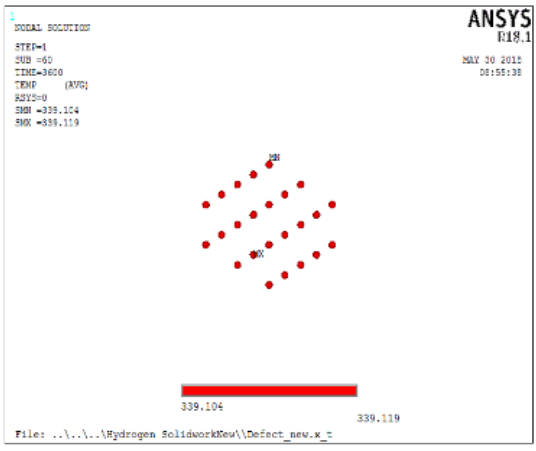

(b)

Fig. 18. Temperature distribution of hydrogen gas inclusion with pouring temperature of $700^{\circ} \mathrm{C}$ at: (a) $60 \mathrm{~s}$ and (b) $3600 \mathrm{~s}$.

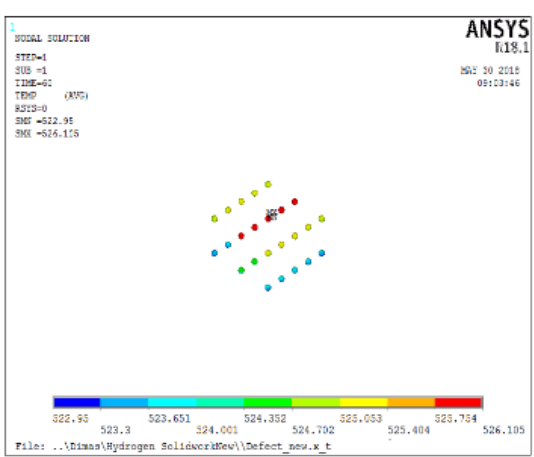

(a)

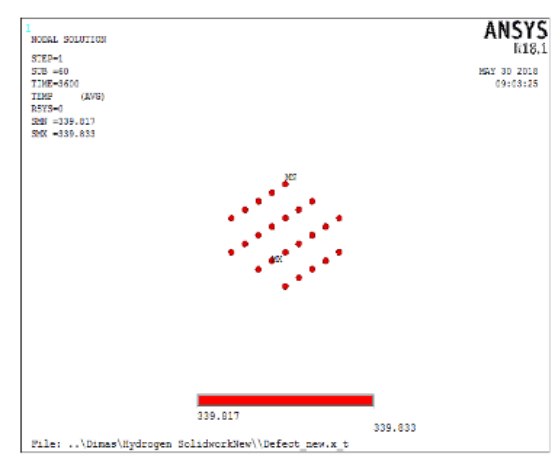

(b)

Fig. 19. Temperature distribution of hydrogen gas inclusion with pouring temperature of $720^{\circ} \mathrm{C}$ at: (a) $60 \mathrm{~s}$ and (b) $3600 \mathrm{~s}$.

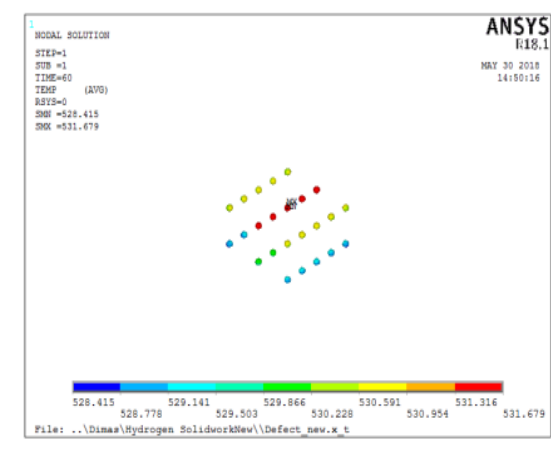

(a)

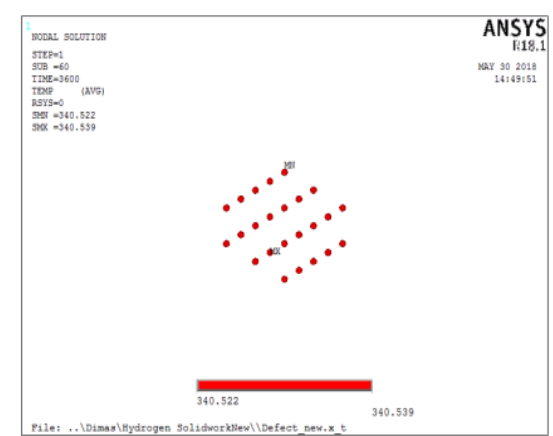

(b)

Fig. 20. Temperature distribution of hydrogen gas inclusion with pouring temperature of $740^{\circ} \mathrm{C}$ at: (a) $60 \mathrm{~s}$ and (b) $3600 \mathrm{~s}$. 
Rendi et al.

\subsection{Cooling Curve}

Fig. 21 shows cooling curve obtained from the simulation and experimental results, respectively. It is noted that the curves are extracted from the same point in the metal slab. It is shown that the simulated cooling rate is faster than that of the experimentation. It is probably due to the sand mold quality which affects heat transfer during the cooling process (Rao, 1999).

Investigation of inverse problems related to the casting process, in particular by using FEM (Hidayat et al., 2020) or other numerical techniques such as meshless (Hidayat et al., 2016; Hidayat et al., 2017) and artificial neural networks (Hidayat, 2015) would be interesting as subjects of further research study.

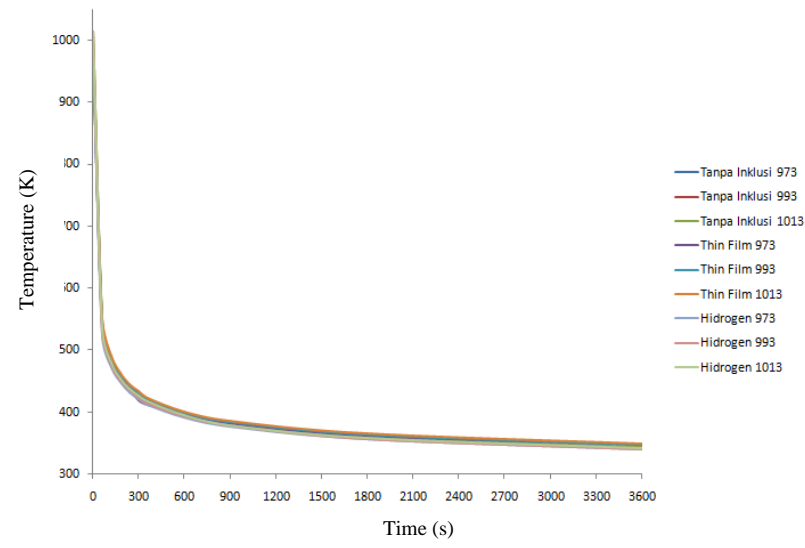

(a)

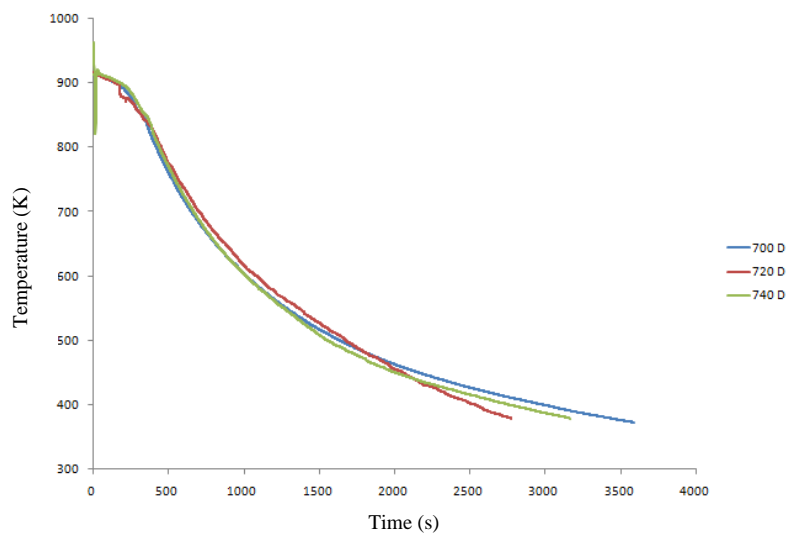

(b)

Fig. 21. Cooling curve obtained from: (a) simulation (b) experimentation.

\section{CONCLUSION}

From the present experimental and numerical study, it can be summarized that:

i) Degassing enhanced significantly the strength of $\mathrm{Al} 6061$ product. The tensile strengths of $\mathrm{Al} 6061$ were 64.30 MPa (pouring temperature of $700^{\circ} \mathrm{C}$ ), $56.99 \mathrm{MPa}$ (pouring temperature of $720^{\circ} \mathrm{C}$ ) and $61.34 \mathrm{MPa}$ (pouring temperature of $740^{\circ} \mathrm{C}$ ), respectively. Without degassing, the tensile strengths of $\mathrm{Al} 6061$ were 35.85 
Rendi et al.

$\mathrm{MPa}$ (pouring temperature of $700^{\circ} \mathrm{C}$ ), $39.57 \mathrm{MPa}$ (pouring temperature of $720^{\circ} \mathrm{C}$ ) and $47.68 \mathrm{MPa}$ (pouring temperature of $740^{\circ} \mathrm{C}$ ), respectively. Hence, the highest tensile strength value has been found to be 64.30 $\mathrm{MPa}$, related to the pouring temperature of $700{ }^{\circ} \mathrm{C}$ with degassing, while the lowest one is $35.85 \mathrm{MPa}$ associated with the pouring temperature of $700{ }^{\circ} \mathrm{C}$ without degassing.

ii) Pouring temperature did not affect significantly to the strength of Al 6061 product, especially when degassing process was carried out.

iii) The presence of thin film and hydrogen gas inclusions affected the cooling rate of the metal slab. Overall, the cooling of the metal slab with thin film inclusion became slower, while the cooling of the metal slab with hydrogen gas inclusions became faster.

\section{Acknowledgments}

Supports from ITS Surabaya are gratefully acknowledged.

\section{References}

American Society for Testing and Materials (2002). ASTM B 557M: Standard Test Methods of Tension Testing Wrought and Cast Aluminum and Magnesium Alloy Products.

Anwar, F.M., Hidayat, M.I.P. and Ramadhani, M. (2020), 'Simulasi Aliran pada Proses Pengecoran Connecting Rod Berbahan Aluminium 7075 untuk Mesin Motor 150 cc dengan Variasi Tinggi Sprue Cetakan dan Temperatur Penuangan Menggunakan Metode Elemen Hingga', Jurnal Teknik ITS, Vol. 9(2), pp. F171F176.

ASM International (2004). ASM Handbook Volume 9: Metallography and Microstructures.

Avner, S.H. (1974), Introduction to Physical Metallurgy, McGraw-Hill, Inc., New York, USA.

Eisaabadi B., G., Davami, P., Kim, S.K. and Varahram, N. (2012), 'Effects of Hydrogen and Oxides on Tensile Properties of Al-Si-Mg Cast Alloys’, Materials Science and Engineering A, Vol. 552, pp. 36-47.

Firdaus, M.B., Hidayat, M.I.P. and Felicia, D.M. (2016), 'Analisa Proses Perpindahan Panas pada Pengecoran Paduan Al-12\%Si dengan Metode Elemen Hingga’, Jurnal Teknik ITS, Vol. 5(2), pp. A492-A496.

Gerrard, J. (2014), 'Inclusions and Hydrogen and Their Effects on the Quality of Direct Chill Cast and Flat Rolled Aluminium Alloys for Aerospace Applications’, PhD thesis, University of Birmingham, UK.

Hidayat, M.I.P. (2015). System Identification Technique and Neural Networks for Material Lifetime Assessment Application. In Q. Zhu \& A.T. Azar (Eds.), Complex System Modelling and Control Through Intelligent Soft Computations, Studies in Fuzziness and Soft Computing 319 (pp. 773-806). Switzerland: Springer International Publishing.

Hidayat, M.I.P., Felicia, D.M., Rafandi, F.I. and Machmudah, A. (2020), "Effects of Sample Shapes and Thickness on Distribution of Temperature inside the Mineral Ilmenite Due to Microwave Heating", Minerals, Vol. 10(4):382, pp. 1-19.

Hidayat, M.I.P., Wahjoedi, B.A. and Parman, S. (2016), "B-spline collocation method for boundary value problems in complex domains", Int. J. Computing Science and Mathematics, Vol. 7(2), pp. 110-125.

Hidayat, M.I.P., Wahjoedi, B.A., Parman, S. and Rao, T.V.V.L.N (2017), "Meshless Local B-Spline Collocation Method for Two-Dimensional Heat Conduction Problems With Nonhomogenous and TimeDependent Heat Sources”, Journal of Heat Transfer, Vol. 139, pp. 071302-1 - 071302-11.

Pariona, M.M. and Mossi, A.C. (2005), 'Numerical Simulation of Heat Transfer During the Solidification of Pure Iron in Sand and Mullite Molds', J. of the Braz. Soc. of Mech. Sci. \& Eng., Vol. 27(4), pp. 399-406.

Rao, P.N. (1999), Manufacturing Technology Foundry, Forming and Welding, McGraw-Hill, Inc., New Delhi, India.

Shamsuddin, M. (2016), Physical Chemistry of Metallurgical Processes, John Wiley \& Sons, Inc., New Jersey, USA.

Totten, G.E. and MacKenzie, D.S. (Eds.) (2003), Handbook of Aluminum Vol. 1: Physical Metallurgy and Processes, Marcel Dekker, Inc., New York, USA.

Yogatama, M.P. Hidayat, M.I.P. and Ramadhani, M. (2020), 'Simulasi Transient Thermal Pada Pengecoran Connecting Rod Berbahan Aluminium 7075 untuk Aplikasi Mesin 150 CC dengan Variasi Material dan Desain Cetakan Menggunakan Metode Elemen Hingga', Jurnal Teknik ITS, Vol. 9(2), pp. F209-F215. 